\title{
Mapping Mobile Payment Adoption: Customers' Trends and Challenges
}

\author{
Vaggelis Saprikis $^{1} \&$ Maro Vlachopoulou ${ }^{2}$ \\ ${ }^{1}$ Department of Management Science and Technology, School of Economic Sciences, University of Western \\ Macedonia, Kozani, Greece \\ ${ }^{2}$ Department of Applied Infromatics, School of Information Sciences, University of Macedonia, Thessaloniki, \\ Greece
}

Correspondence: Vaggelis Saprikis, Department of Management Science and Technology, School of Economic Sciences, University of Western Macedonia, 50100, Kozani, Greece. E-mail: esaprikis@uowm.gr

Received: June 3, 2021

doi:10.5539/ijbm.v16n9p82
Accepted: July 20, 2021

Online Published: August 9, 2021

URL: https://doi.org/10.5539/ijbm.v16n9p82

\begin{abstract}
The continuous advancement of the mobile technology industry and the wide acceptance of mobile devices worldwide have provided great prospects to customers regarding their monetary transactions. As a result, numerous individuals use their mobile devices, mainly their smartphone; to pay online and even more are expected to take advantage of the mobile payments in the near future. This study conducts an up-to-date review to survey the landscape of individuals' behavioral intention to adopt m-payments systems and services in the last five years (2015-2019 period). In specific, the aim of this review paper is twofold. First, it collects and summarizes the review papers that focus on customers' m-payment adoption intention as an umbrella review. Second, it analyzes all recently top quantitative primary research papers that examined the aforementioned topic and presents a detailed examination of their objectives and research outcomes as a scoping review. Both of these analyzes are expected to increase the understanding of $\mathrm{m}$-payments adoption and their underlying factors that influence individuals' decision to adopt them, as well as reveal research gaps. Consequently, the paper aims to be a useful tool for mapping the research trends in current literature regarding mobile payment.
\end{abstract}

Keywords: mobile payment, intention to adopt, consumer mobile payment behavior, umbrella review, scoping review

\section{Introduction}

Mobile payment (m-payment) is an up-to-date and highly interested topic and a field that is evolving really fast as it takes advantage of the continuous progress of the mobile technology industry and the wide acceptance of the mobile devices (m-devices) and systems. M-payment is defined as any type of individual use of mobile devices linked with a wireless network supporting the process of financial interactions. In 2007, Mallat defined m-payment as a monetary, directly or via an intermediate transaction, from the buyer to the seller by the use of m-device. Similarly, Liébana-Cabanillas et al. (2014) mentioned that any type of customer's or merchant's activity linking a mobile device with a wireless telecommunication network, enabling the successful completion of a financial transaction can be characterized as m-payment. Thus, individuals as well as firms can utilize m-devices, mainly smartphones, and take advantage of their ability to be connected with wireless communication technologies aiming at paying for goods or services (Dahlberg et al. 2008). Overall, according to (Chandra 2017), m-payment has some specific characteristics in any economic transaction which are ease of use, atomicity, availability, confidentiality, security and profitability.

The wide acceptance of m-payments as a novel payment channel tempted various researchers to examine the topic. Therefore, there have been an increase in the volume of literature concerning m-payments, most of which are from the perspective of consumers. Among these investigations, a number of variables (or factors) were selected to study m-payment services and systems adoption; and different research models were applied. However, despite the fact that numerous studies have been conducted about the adoption of m-payments, there is still a need to systematically bring this research efforts together in order to inform m-payment providers and potential users about enablers and inhibitors affecting the adoption of m-payment services based on several technology adoption frameworks; and used in different geographical and cultural areas during the last years. This 
attempt aims to reveal the contemporary factors that influence the adoption of m-payments by the customers, and inform future research about the main gaps of the previous literature.

The scope of this paper is to increase the understanding related to mobile payments adoption and their underlying factors that influence individuals' decision of usage of m-payments, reviewing m-payment adoption papers per continent and country. Furthermore, the basic framework theories and intention models most frequently utilized to investigate m-payments customers' acceptance have been explored.

The main contribution of this research is a) to collect and summarize the review papers published between 2015 and 2019 as an umbrella review and b) to analyze all recently top quantitative primary research papers which investigated individuals' mobile payment adoption intention the last five years -2015 to 2019- as a scoping review, with the aim to present an updated view based on the most recent empirical studies on this topic; and identify issues that have been examined or have not deeply investigated; and need to be updated taking into consideration the recent research. In specific, our study conducts an up-to-date review to survey the landscape of individuals' behavior towards their intention to adopt m-payments systems along with the following Research Questions (RQ):

RQ1: Which publishing companies have demonstrated the most papers and which of them are highly cited?

RQ2: Which are the most active continents and countries that have undertaken m-payment adoption studies?

RQ3: Which technology adoption theories and intention models have been used more frequently the last years?

RQ4: What factors are enablers or inhibitors regarding the adoption of m-payment?

RQ5: Among all these factors, which are used more frequently and found to be the most significant ones?

In our study we address the above mentioned issues by systematically reviewing the m-payment adoption literature published in recent years (2015-2019 period). Therefore, it is useful to study the relevant trends from the recent literature to predict possible adverse reactions when adopting mobile payments, as well as to provide constructive suggestions for future research and practice.

The following session outlines the methodologies adopted to both umbrella review and scoping review. The paper, then, presents the outcomes of the relevant literature before recommending a series of future research proposals.

\section{Research Methodology}

Two different research approaches were followed with the aim to respond to both aims of the study, which are an umbrella review and a scoping review regarding individuals' m-payment adoption. The combination of them is considered as an opportunity for providing a 'big picture' of the most recent reviews and empirical research studies in this topic; and identify issues that have been examined or have not deeply investigated and need to be further studied in the future. Moreover, the current review helps to answer the research questions of this paper.

Therefore, the first aim of the article is to collect and summarize the review papers published between 2015 and 2019 as an umbrella review. Umbrella review, also called an overview of reviews, is a comparatively new technique of evidence synthesis that has emerged as a result of the continuously increasing in the number of systematic reviews papers published. According to Becker and Oxman (2008) and Smith et al. (2011), it summarizes related evidence from various SLRs (Systematic Literature Review) into one handy and practical paper with the aim to response to a specific research question. Overall, this type of review employs the majority of the analysis procedure, techniques and methodological steps which are utilized in systematic literature reviews (Paré et al. 2015). Therefore, it can be inferred that it can provide a complete guide to gain a clean understanding of a topic. This is the reason why it was selected as the most preferable type of review to address the first aim of this paper.

A detailed investigation in the following databases conducted. In specific, 1) ACM Digital Library, 2) AIS eLibrary, 3) Emerald Insight, 4) Google Scholar, 5) Inderscience Publishers, 6) IEEE Xplore Digital Library, 7) ProQuest Direct, 8) Wiley and Sons, 9) Taylor and Francis, 10) Sage Journals, 11) Springer Link and 12) Science Direct were examined in order to search for m-payment literature review papers. The search terms were ("mobile payment adoption" or "m-payment adoption") and ("literature review" or "critical review" or "systematic literature review"). A total of fifteen literature review papers were revealed. Then, all papers were further screened through their keywords and by reading the abstract. Five of them were excluded because they examined a specific m-payment technology, such as mobile wallets, NFC payments; or dealt with technical aspects of the technology. Therefore, the analysis revealed a total of ten articles that investigated the topic.

Afterwards, a comprehensive collection, analysis and presentation of all top quantitative primary research papers 
which investigated individuals' m-payment adoption intention the last five years -2015 to 2019- was conducted aimed to respond to the second aim of the study and answer to the aforementioned research questions of the scoping review. Specifically, a scoping review intends to present a first sign of the prospective extent and nature of the available literature on a specific subject (Arksey \& O'Malley, 2005; Daudt et al., 2013; Levac et al., 2010). According to Kitchenham et al. (2011), Rumrill et al. (2010) and Arksey and O'Malley (2005), researchers might conduct such a review when they want to investigate the size, the variety and the nature of research activities, detect research gaps in the existing studies, or determine the importance of carrying out a full systematic review. Scoping reviews have a tendency to focus on the extent of coverage of the literature rather than the depth of coverage (Rumrill et al., 2010; Arksey \& O'Malley, 2005). According to Tricco et al. (2016), they are utilized to reveal knowledge gaps, define research plans and detect suggestions for decision-making. The main goal of such a review is to be as comprehensive as possible to the topic examined (Arksey \& O'Malley, 2005). Exclusion and inclusion criteria should be applied to help researchers exclude literature which are not aligned with the primary research questions (Paré et al. 2015). According to Anderson et al. (2008), if scoping reviews focus on investigating the nature and the extent of a broad subject are characterized as mapping reviews. The research questions in these studies are broad and regularly are associated with research trends. Paré et al. (2015) pointed out, however, that there is not any defined plan to systematically review the literature based on this type of review. As an alternative, researchers may just consider setting a precise timeframe for the literature to be mapped; for example, investigate the studies that have been conducted in the last 5 years. Therefore, regarding the methodology applied for the final selection of the papers, it was conducted in four steps which are as follows.

First, the study begins looking for empirical research publications in the following databases: 1) ACM Digital Library, 2) AIS eLibrary, 3) Emerald Insight, 4) Google Scholar, 5) Inderscience Publishers, 6) IEEE Xplore Digital Library, 7) ProQuest Direct, 8) Wiley and Sons, 9) Taylor and Francis, 10) Sage Journals, 11) Springer Link and 12) Science Direct were "mobile payment adoption" or "m-payment adoption". All papers that did not include m-payment in their title were excluded.

Second, after the initial assessment, all selected articles were further screened through their keywords and by reading the abstract. A number of papers concentrated on the monetary impact of m-payment were excluded. There were also removed papers that deal with specific technical aspects, such as communication protocols and processes, as well as security issues.

Third, the reference sections of the remained papers were also reviewed to find potential additional m-payment empirical studies (review backward reference list checking). After deleting the duplicate and non-full text articles, a total of 183 papers from the 2015-2019 period was remained.

Forth, each of them was further reviewed based on the following inclusion criteria:

- Involved m-payment adoption intention as a primary condition.

- Conducted a quantitative primary study.

- Was written in English language.

- Did not examine a specific m-payment technology, such as mobile wallets, NFC payments, etc.

- Proposed and examined a well-developed conceptual research framework or model with constructs impacting adoption.

- Was published in a peer-reviewed academic journal that was included in one of the four quartiles -Q1-Q4 of the SCImago Journal Rank.

After a persistent and detailed examination process 27 out of the 183 empirical papers met the aforementioned criteria and comprised the final sample (Table 2). A number of papers that focused on retailers or enterprises $\mathrm{m}$-payment adoption were excluded because there were not relevant to individuals' adoption. There were also a number of rejected papers that examined m-payment via a behavioral theoretical model/ framework but were not focused on m-payment adoption. For example, various articles focused on continuance intention or level of m-payment use. Furthermore, primary studies stating only percentages of adopters were excluded as well. Therefore, the criteria provided revealed the most significant empirical studies that had research models/ frameworks and investigated individuals' $\mathrm{m}$-payment adoption from a broad perspective; and were published in the top academic journals as well.

\section{Mobile Payment Adoption Literature Review}

This section describes the results of both umbrella review and scoping review. The section starts with the analysis and presentation of 10 literature review papers (umbrella review) within the 2015-2019 period. 
Afterwards, the scoping review of the top quantitative empirical papers which investigated customers' m-payment adoption intention the last five years was conducted to answer the research questions.

\subsection{Umbrella Review}

Thus, concerning mobile payment investigation, it immediately began since the first m-payment transaction took place in 1997. Dahlberg et al. (2015) conducted a critical systematic literature review in order to assess the research improvements regarding the m-payment systems between 2007 and 2014; and critically analyzed differences and similarities with their previous results (Dahlberg et al. 2008). In specific, the aim was to compare outcomes and statistics about the m-payment ecosystem, such as specific research topics, usage of several research methodologies and approaches, etc., between the two periods (1998-2006 versus 2007-2014). The literature review of 2015 revealed that research on this subject has continued to focus mainly on technology aspects and individuals' adoption, without extending the research efforts to the provision of additional knowledge on remaining factors affecting the m-payment ecosystem. Finally, they proposed new prospects to strengthen future m-payment research avenues.

Based on trends identified in m-payment research, Dennehy and Sammon (2015) concluded that the investigation of $\mathrm{m}$-payment constitutes an established research area that will continue to receive increased attention from diverse disciplines in the coming years, realizing the potential and the enrichment of m-payment services, as the adoption of such services is becoming more and more imperative. Customers' adoption still seems to be of interest to many researchers to date, but the focus remains on investigating the adoption of payments in specific countries separately, while a comparison of the results of the survey, which was conducted in more than one country with reference to differences between them, does not attract yet the interest of researchers. Furthermore, regarding adoption issues, recently studies examined in specific technology, security and architecture.

Results of literature analysis conducted by Patil et al. (2017), revealed that first of all performance expectancy and perceived usefulness, followed by perceived ease of use are the factors affecting positive consumers' behavioral intention towards mobile payment services, while perceived risk appears as the main inhibitor. Furthermore, regarding the methodology used to study factors affecting the adoption of individuals regarding m-payment, the majority of researchers adopted Technology Acceptance Model (TAM) and several extensions of this methodology followed in more recent years by the Unified Theory of Acceptance and Use of the Technology (UTAUT).

Lai (2017a) provides a useful knowledge by examining in detail the development of methodologies and theories of technology adoption based on the literature review with emphasis on the possible application of the innovation of the single electronic payment platform. The results of this work can help researchers understand the appropriate methodology they will choose.

In 2019 Abhipsa Pal et al. stated research questions regarding the important contextual factors that influence $\mathrm{m}$-payment adoption in the current literature. The outcome of this effort was the development of a "context-based framework for m-payment adoption and use" that can be used as a guideline for future researchers. Finally, they conducted an interview empirical study exploring m-payment users in India to check the validity of their proposed model.

Furthermore, Liu et al. (2019a) mentioned that factors such as perceived usefulness, perceived ease of use, trust and perceived risk, social influence, should be carefully examined and integrated into payment services and their promotion in order to motivate consumers' behavior.

The main purpose of the study of Tansakul et al. (2019) was to review various peer-reviewed scholarly articles to point out the important factors that directly influence user behavior and m-payment adoption based on different adoption theories and methods.

According to results of the research study of Tse et al. (2019), more attention has to be paid to security factors, while the main factors identified as affecting customers' adoption of m-payment products are risk issues, age and gender, and finally the type of mobile payment platforms.

Furthermore, results of Harris et al. (2019) review analysis supported the previous study from Dahlberg et al. (2015). In specific, they also confirmed that the TAM and UTAUT/UTAU2 models have dominated the investigations into m-payment systems' adoption. To better investigate the topic from a personal use perspective, they proposed a "risk/ trust valence" framework incorporating security and privacy constructs.

Finally, the systematic literature review conducted in 2019 by Karsen et al. revealed 44 factors that influence individuals on using m-payment in financial institutions as the basis for the development of mobile payment 
products. In specific, they propose 17 key technological factors which can be used to develop up to date mobile payment services appropriate for the needs of financial institutions.

Table 1 summarizes the literature review papers along with their characteristics. These are their objectives, their research outcomes and their review period.

Table 1. Mobile payment adoption literature review papers - 2015-2019 (10 review papers)

\begin{tabular}{|c|c|c|c|c|}
\hline \# & $\begin{array}{lll}\text { Literature } & \text { review } & \text { paper } \\
\text { (author/s) } & & \end{array}$ & Objectives & $\begin{array}{l}\text { Review period } \\
\text { and number of } \\
\text { papers }\end{array}$ & Research Outcomes \\
\hline 1 & Dahlberg et al. 2015 & $\begin{array}{l}\text { To critically analyze m-payment } \\
\text { research (2007-2014) and compare } \\
\text { statistics and methodologies about } \\
\text { m-payment systems between the two } \\
\text { periods (1998-2006 vs 2007-2014) }\end{array}$ & $\begin{array}{lr}87 & \text { papers } \\
\text { between } & 2007 \\
\text { and } 2014 & \end{array}$ & $\begin{array}{l}\text { Technology and consumer } \\
\text { adoption are still the } \\
\text { dominant } \\
\text { followed by ecosystem } \\
\text { research. }\end{array}$ \\
\hline 2 & Dennehy and Sammon 2015 & $\begin{array}{l}\text { A review of literature aimed at identifying } \\
\text { the key research themes and methodologies } \\
\text { investigated on m-payments }\end{array}$ & $\begin{array}{l}\text { Review of the } \\
20 \text { most cited } \\
\text { papers since } \\
1999 \text { and the } 20 \\
\text { most recently } \\
\text { published papers } \\
\text { since August } \\
2014 \quad\end{array}$ & $\begin{array}{l}\text { Consumer adoption remains } \\
\text { the most popular area of } \\
\text { focus by researchers. } \\
\text { Specifically, recently studies } \\
\text { examine technology, security } \\
\text { and architecture regarding } \\
\text { adoption issues. }\end{array}$ \\
\hline 3 & Lai 2017a & $\begin{array}{l}\text { To present the literature review of theories } \\
\text { and methodologies leading to an } \\
\text { innovative "single platform e-payment } \\
\text { theoretical framework" }\end{array}$ & - & $\begin{array}{l}\text { Aims to help future } \\
\text { researchers conceptualize, } \\
\text { distinguish and comprehend } \\
\text { underlying technology } \\
\text { models and theories related } \\
\text { to m-payment adoption. }\end{array}$ \\
\hline 4 & Patil et al. 2017 & $\begin{array}{l}\text { To review and analyze digital and } \\
\text { m-payment adoption and use }\end{array}$ & - & $\begin{array}{l}\text { Most significant influencing } \\
\text { factors related to customers' } \\
\text { behavioral intention: } \\
\text { performance expectancy \& } \\
\text { perceived usefulness, } \\
\text { perceived ease of use. } \\
\text { Inhibitor to the adoption of } \\
\text { m-payments: perceived risk. } \\
\text { TAM (extensions) followed } \\
\text { by UTAUT usage to explore } \\
\text { consumer adoption to } \\
\text { m-payment. }\end{array}$ \\
\hline 5 & Pal et al. 2019 & $\begin{array}{l}\text { To study the factors that influence } \\
\text { m-payment adoption in the extant literature } \\
\text { and contextual variables }\end{array}$ & $\begin{array}{l}79 \text { papers up to } \\
2018\end{array}$ & $\begin{array}{l}\text { Development of a } \\
\text { context-based framework for } \\
\text { m-payment adoption and use. }\end{array}$ \\
\hline 6 & Liu et al. 2019a & $\begin{array}{l}\text { A meta-analysis was conducted to build } \\
\text { consensus about what are the factors that } \\
\text { significantly affect consumers' m-payment } \\
\text { behavior }\end{array}$ & $\begin{array}{lr}61 & \text { papers } \\
\text { between } & 2008 \\
\text { and } 2017 & \end{array}$ & $\begin{array}{l}\text { Factors with significant } \\
\text { impact over individuals' } \\
\text { intention to use m-payment: } \\
\text { perceived usefulness, } \\
\text { perceived ease of use, } \\
\text { perceived risk, trust, social } \\
\text { influence. }\end{array}$ \\
\hline 7 & Tansakul et al. 2019 & $\begin{array}{l}\text { The main purpose was to review various } \\
\text { peer-reviewed articles in order to indicate }\end{array}$ & $\begin{array}{lr}39 & \text { papers } \\
\text { between } & 2015\end{array}$ & 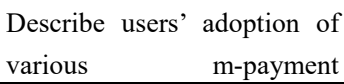 \\
\hline
\end{tabular}




\begin{tabular}{|c|c|c|c|c|}
\hline & & $\begin{array}{l}\text { the main adoption factors that directly } \\
\text { affect users' behavioral intention }\end{array}$ & and 2018 & $\begin{array}{l}\text { approaches. } \\
\text { encompassing methods, } \\
\text { theories, } \\
\text { adoption models, and } \\
\text { variables of the adoption } \\
\text { models. }\end{array}$ \\
\hline 8 & Tse et al. 2019 & $\begin{array}{l}\text { This paper studies the factors enabling and } \\
\text { hindering m-payments based on research } \\
\text { articles in recent years }\end{array}$ & 34 papers & $\begin{array}{l}\text { M-payment acceptance is } \\
\text { driven by the development of } \\
\text { a m-payment platform, } \\
\text { easy-to-use and more secure. }\end{array}$ \\
\hline 9 & Harris et al. 2019 & $\begin{array}{l}\text { To review previous research that focuses } \\
\text { on consumer m-payment adoption and } \\
\text { presents the major methodologies used }\end{array}$ & $\begin{array}{l}57 \text { papers up to } \\
\text { fall } 2018\end{array}$ & $\begin{array}{l}\text { TAM and UTAUT/ UTAUT2 } \\
\text { were the primary models } \\
\text { utilized. The authors } \\
\text { proposed the "risk/trust } \\
\text { valence framework" taking } \\
\text { into consideration } \\
\text { security and privacy } \\
\text { antecedents. }\end{array}$ \\
\hline 10 & Karsen et al. 2019 & $\begin{array}{l}\text { To present the key technological factors } \\
\text { used in m-payment }\end{array}$ & $\begin{array}{lr}54 & \text { papers } \\
\text { between } & 2014 \\
\text { and } 2019 & \end{array}$ & $\begin{array}{l}44 \text { factors } \\
\text { individuals on using } \\
\text { m-payment in financial } \\
\text { institutions. Furthermore, } \\
\text { there are } 17 \text { basic } \\
\text { technological related factors } \\
\text { that impact m-payments. }\end{array}$ \\
\hline
\end{tabular}

\subsection{Scoping Review}

Regarding the scoping review, the research questions along with their results are as follows.

RQ1: Which publishing companies have demonstrated the most papers and which of them are highly cited?

The findings present that the majority of the empirical papers were published very recently; in the year of 2019 (9), followed by 2015 (7), 2016 (5), 2018 (5) and 2017 (1) (Table 2). Regarding publishing companies, Elsevier tops the list (6), followed by Taylor and Francis (5), Emerald (3), Inderscience (3), Springer (3), Wiley (3), Sage (2), MDPI (1) and SERSC (1).

Table 2. Mobile payment adoption empirical papers, 2015-2019

\begin{tabular}{llll}
\hline$\#$ & Authors & Year & Source \\
\hline 1 & Xin et al. & 2015 & Taylor and Francis \\
2 & Koenig-Lewis et al. & 2015 & Taylor and Francis \\
3 & Yan and Yang & 2015 & Science and Engineering Research Support Society (SERSC) \\
4 & Musa et al. & 2015 & Inderscience \\
5 & Slade et al. & 2015 & Wiley \\
6 & Teo et al. & 2015 & Emerald \\
7 & Teo et al. & 2015 & Inderscience \\
8 & Phonthanukitithaworn et al. & 2016 & Sage \\
9 & Phonthanukitithaworn et al. & 2016 & Emerald \\
10 & Qasim and Abu-Shanab & 2016 & Springer \\
11 & Ting et al. & 2016 & Elsevier \\
12 & Oliveira et al. & 2016 & Elsevier \\
13 & Gao and Waechter & 2017 & Springer \\
14 & Humbani and Wiese & 2018 & Taylor and Francis \\
15 & Shankar and Datta & 2018 & Sage \\
16 & Su et al. & 2018 & Taylor and Francis \\
17 & Johnson et al. & 2018 & Elsevier \\
18 & Liébana-Cabanillas et al. & 2018 & Elsevier \\
\hline
\end{tabular}




\begin{tabular}{llll}
\hline 19 & Sharma et al. & 2019 & Taylor and Francis \\
20 & Lee et al. & 2019 & Elsevier \\
21 & Chen et al. & 2019 & MDPI \\
22 & Park et al. & 2019 & Elsevier \\
23 & Shahin et al. & 2019 & Inderscience \\
24 & Sinha et al. & 2019 & Emerald \\
25 & Park et al. & 2019 & Wiley \\
26 & Liu et al. & $2019 \mathrm{~b}$ & Springer \\
27 & Moorthy et al. & 2019 & Wiley \\
\hline
\end{tabular}

From the total of the 27 papers, there were only four journals -Computers in Human Behavior, Journal of Retailing and Consumer Services, Information Systems Frontier and International Journal- with two publications during this 5-year period. The rest of the journals demonstrated one publication. Regarding the most cited papers, Table 3 presents the top- 5 articles. As it is clearly depicted, Oliveira's et al. (2016) paper tops the list with 472 citations followed by Slade's et al (2015) article with 372 citations.

Table 3. List of the top-5 most cited papers, as of October 5th 2020

\begin{tabular}{llllc}
\hline$\#$ & Authors & Year & Journal & Citations \\
\hline 1 & Oliveira et al. & 2016 & Computers in Human Behavior & 472 \\
2 & Slade et al. & 2015 & Psychology and Marketing & 372 \\
3 & Teo et al. & 2015 & Industrial Management and Data & 213 \\
4 & Koenig-Lewis et al. & 2015 & Systems & 139 \\
5 & Qasim and Abu-Snahab & 2017 & The Service Industries Journal & 117 \\
\hline
\end{tabular}

RQ2: Which are the most active continents and countries that have undertaken m-payment adoption studies?

Concerning the regions where researchers were focused on, the majority of the papers were based on respondents from Asian countries (Table 4). China and Malaysia were the most preferred ones resulting to the publication of four papers on each of them. However, very few studies from the Europe and the Americas were revealed. According to eMarketer's global m-payment users' report (Merchantsavvy, 2020), there were many countries in both continents with slow and very slow adoption rates in 2019. For example, m-payment adopt rate is $10.2 \%$ in Mexico, $12.5 \%$ in Germany, $14.6 \%$ in Argentina and Brazil; and 15.6\% in France among smartphone users. Similarly, a comparative small number of studies were found out from Africa and Oceania where m-payment adoption rates are expected to be even lower.

Table 4. Mobile payment adoption papers per continent and country

\begin{tabular}{|c|c|c|c|}
\hline Continent & Country & Quantity & Reference \\
\hline Africa & South Africa & 1 & Humbani and Wiese 2018 \\
\hline Americas & USA & 2 & Johnson et al. 2018; Park et al. 2019a \\
\hline \multirow{9}{*}{ Asia } & China & 4 & Yan and Yang 2015; Su et al. 2018; Chen et al. 2019; Liu et al. 2019b \\
\hline & India & 2 & Shankar and Datta 2018; Sinha et al. 2019 \\
\hline & Iran & 1 & Shahin and Mahyari 2019 \\
\hline & Jordan & 1 & Qasim and Abu-Shanab 2016 \\
\hline & Malaysia & 4 & Teo et al. 2015a,b; Ting et al. 2016; Moorthy et al. 2019 \\
\hline & Oman & 1 & Sharma et al. 2019 \\
\hline & Qatar & 1 & Musa et al. 2015 \\
\hline & South Korea & 2 & Park et al. 2019b; Lee et al. 2019 \\
\hline & Thailand & 2 & Phonthanukitithaworn et al. 2016a,b \\
\hline \multirow{4}{*}{ Europe } & France & 1 & Koenig-Lewis et al. 2015 \\
\hline & Portugal & 1 & Oliveira et al. 2016 \\
\hline & Spain & 1 & Liébana-Cabanillas et al. 2018 \\
\hline & UK & 1 & Slade et al. $2015 \mathrm{~b}$ \\
\hline \multirow{2}{*}{ Oceania } & Australia & 1 & Gao and Waechter 2017 \\
\hline & New Zealand & 1 & Xin et al. 2015 \\
\hline
\end{tabular}


RQ3: Which technology adoption theories and intention models have been used more frequently the last years?

Out of the 27 papers, in 8 studies the Technology Acceptance Model (TAM) was applied (Table 5). Specifically, in all of them the researchers tried to overcome the limitations of TAM to explain behavioral adoption intention by enhancing its original model with other constructs. TAM was also used as a part of a combined proposed conceptual model where more than one of the basic technology adoption theories was simultaneously applied. The presentation of the technology adoption theories and intention models utilized from the researchers of the sample is depicted on Table 5.

Table 5. Technology adoption theories and intention models

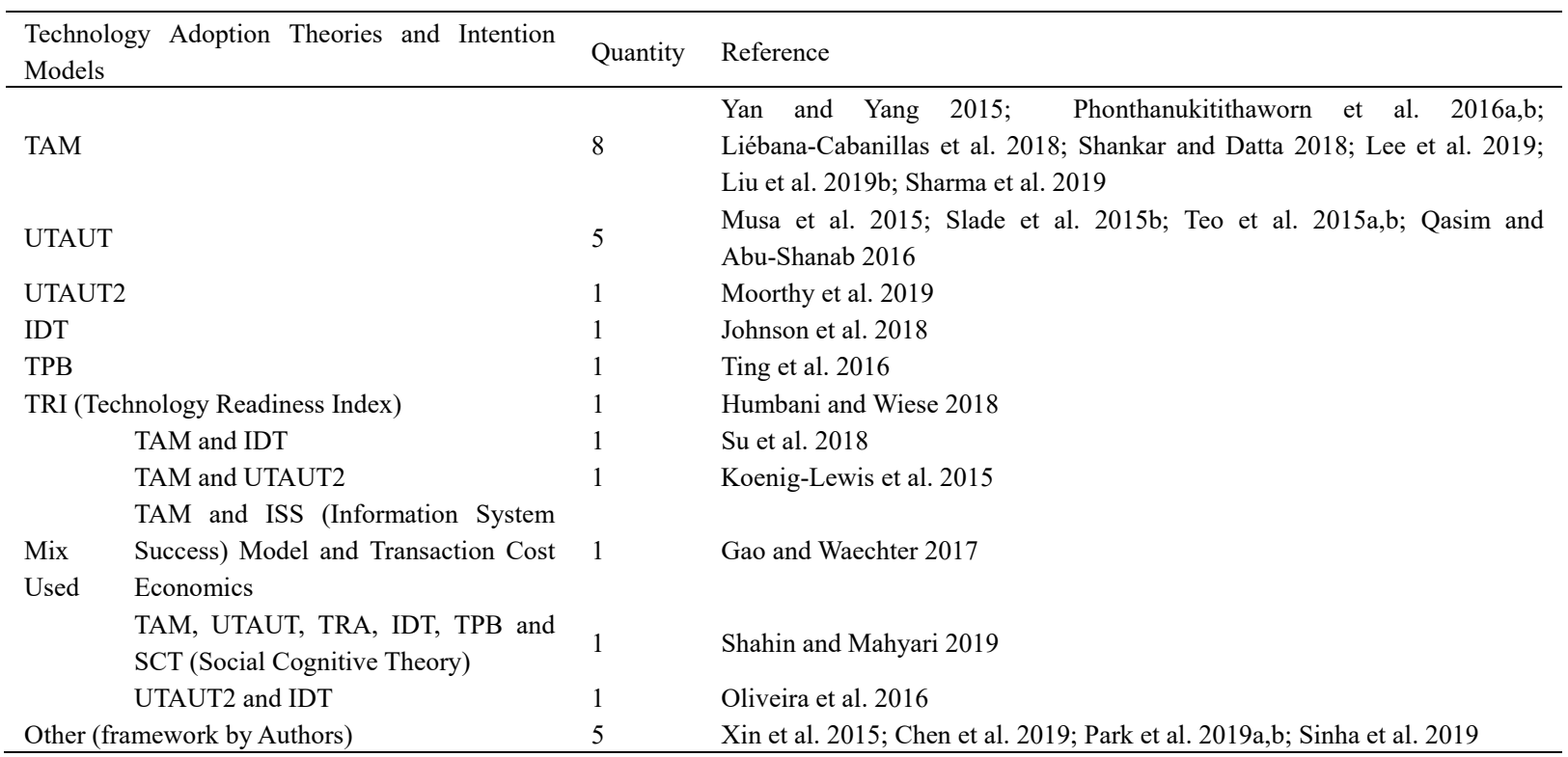

RQ4: What constructs/ factors are enablers or inhibitors regarding the adoption of m-payment?

RQ5: Among all these factors, which are used more frequently and found to be the most significant ones?

Table 6 presents the factors that were dispersed in the m-payment adoption literature. The analysis revealed 32 enablers and 7 inhibitors in the 27 papers. Researchers confirmed that some of the factors did impact m-payment adoption intention only directly (e.g., facilitating conditions and governmental support) or indirectly (e.g., customization and technology anxiety). However, there are quite a few of them that had a dual effect -directly and indirectly- as well. For example, Oliveira et al. (2016) and Gao and Waechter (2017) proved that compatibility and convenience impact the dependent variable in both ways; directly and indirectly, via their conceptual models in correspondence.

Table 6. Constructs/ Factors that encourage or inhibit m-payment adoption

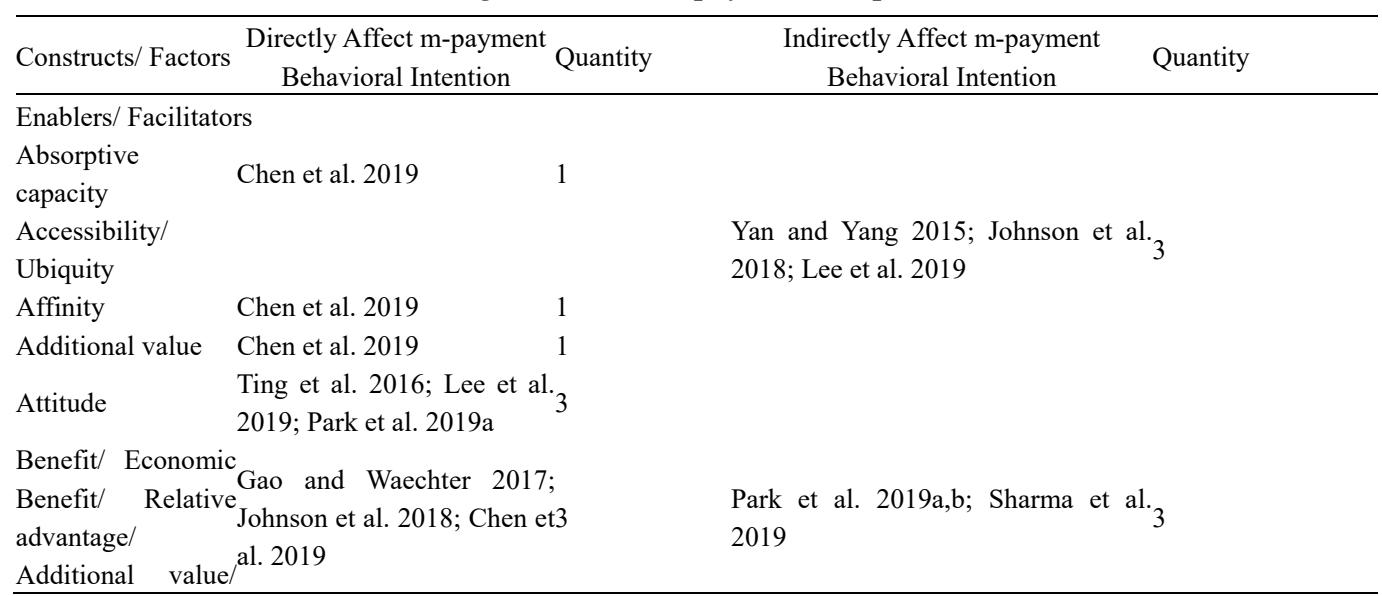


Experiential benefit

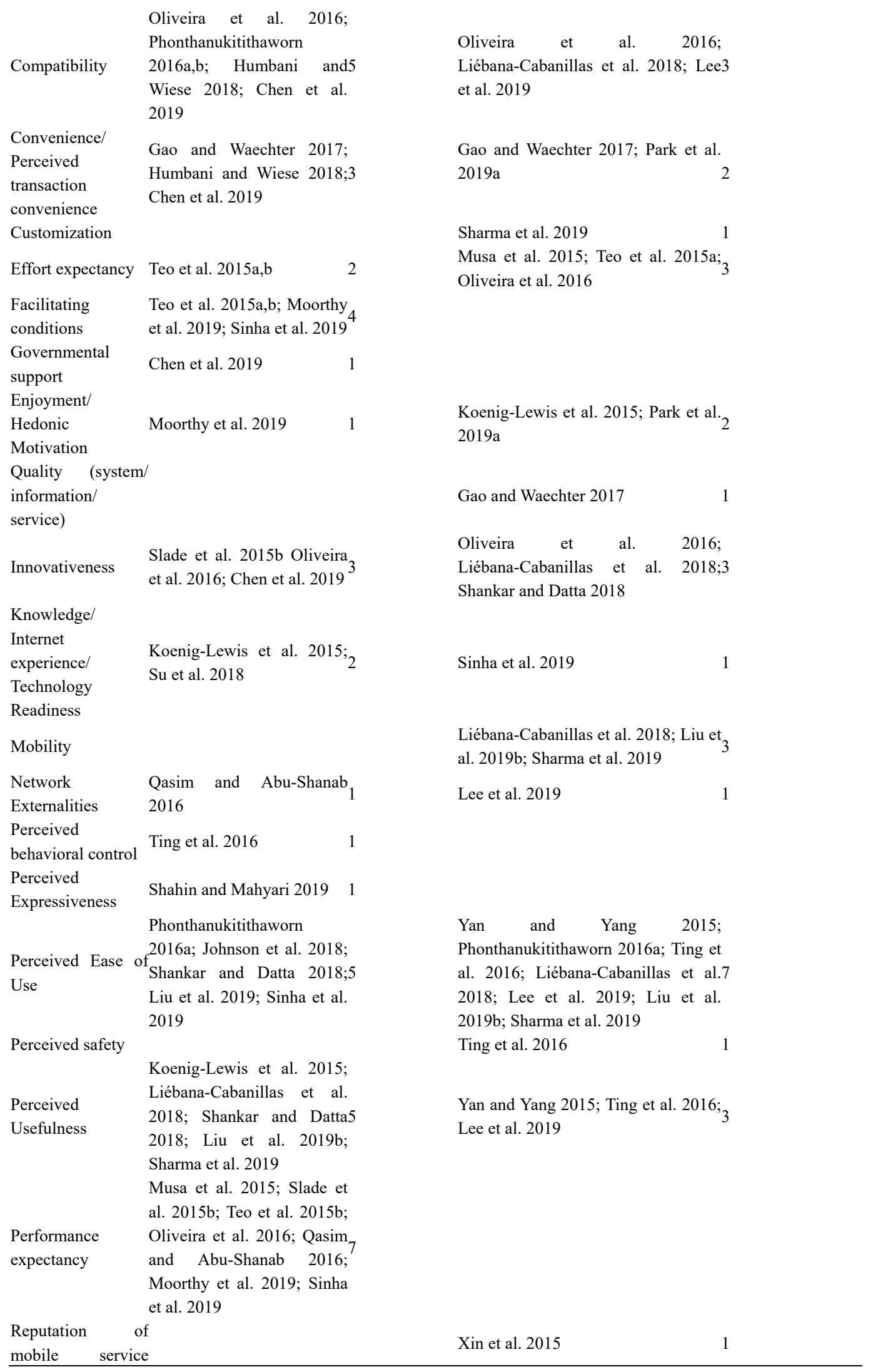




\begin{tabular}{|c|c|c|}
\hline \multicolumn{3}{|c|}{ provider/vendor } \\
\hline $\begin{array}{l}\text { Security/ Structura } \\
\text { assurance }\end{array}$ & $\begin{array}{l}\text { Musa et al. 2015; Oliveira et } \\
\text { al. 2016; Johnson et al. } \\
\text { 2018; Liébana-Cabanillas et6 } \\
\text { al. 2018; Moorthy et al. } \\
\text { 2019; Sharma et al. } 2019\end{array}$ & $\begin{array}{l}\text { Xin et al. 2015; Yan and Yang 2015; } \\
\text { Park et al. 2019a }\end{array}$ \\
\hline Self-Efficacy & Shankar and Datta $2018 \quad 1$ & $\begin{array}{l}\text { Shankar and Datta 2018; Sharma et } \\
\text { al. } 2019\end{array}$ \\
\hline $\begin{array}{l}\text { Social influence/ } \\
\text { Subjective Norms }\end{array}$ & $\begin{array}{l}\text { Koenig-Lewis et al. 2015; } \\
\text { Musa et al. 2015; Slade et } \\
\text { al. 2015b; Oliveira et al. } \\
\text { 2016; Phonthanukitithaworn9 } \\
\text { 2016a,b; Qasim and } \\
\text { Abu-Shanab 2016; Ting et } \\
\text { al. 2016; Sinha et al. } 2019\end{array}$ & $\begin{array}{l}\text { Koenig-Lewis et al. 2015; } \\
\text { Liébana-Cabanillas et al. 2018; } \\
\text { Shankar and Datta 2018; Park et al. } \\
\text { 2019a }\end{array}$ \\
\hline Transaction speed & Teo et al. $2015 \mathrm{a}$ & Teo et al. $2015 \mathrm{a}$ \\
\hline Trialability & $\begin{array}{l}\text { Teo et al. 2015b; Xin et al. } \\
\text { 2015; Yan and Yang 2015; } \\
\text { Phonthanukitithaworn }\end{array}$ & Johnson et al. 2018 \\
\hline Trust & $\begin{array}{l}\text { 2016a,b; Qasim and } \\
\text { Abu-Shanab 2016; Gao and11 } \\
\text { Waechter 2017; Shankar } \\
\text { and Datta 2018; Park et al. } \\
\text { 2019b; Shahin and Mahyari } \\
\text { 2019; Sharma et al. } 2019\end{array}$ & $\begin{array}{l}\text { Slade et al. } 2015 \text { b; Ting et al. } 2016 \text {; } \\
\text { Gao and Waechter 2017; Lee et al. } \\
2019\end{array}$ \\
\hline $\begin{array}{l}\text { Visibility } \\
\text { Inhibitors }\end{array}$ & Johnson et al. 2018 & \\
\hline Asset specificity & Phonthanukitithaworn & Gao and Waechter 2017 \\
\hline Cost & $\begin{array}{l}\text { 2016a; Humbani and Wiese3 } \\
\text { 2018; Liu et al. 2019b }\end{array}$ & Teo et al. 2015a \\
\hline $\begin{array}{l}\text { Insecurity } \\
\text { Opportunism of }\end{array}$ & Humbani and Wiese $2018 \quad 1$ & \\
\hline $\begin{array}{l}\text { mobile service } \\
\text { provider/vendor }\end{array}$ & & Xin et al. 2015 \\
\hline Technology anxiety & $\begin{array}{l}\text { Lewis et al. 2015; } \\
\text { Phonthanukitithaworn }\end{array}$ & Park et al. 2019a \\
\hline $\begin{array}{l}\text { Risk } \\
\text { (Environmental }\end{array}$ & $\begin{array}{l}\text { 2016a,b; Slade et al. 2015b; } \\
\text { Wiese 2018; Chen et al.8 }\end{array}$ & $\begin{array}{lcc}\text { Xin et } & \text { al. } & \text { 2015; } \\
\text { Phonthanukitithaworn } & 2016 \mathrm{~b} ; 4\end{array}$ \\
\hline Risk/ Privacy Risk) & $\begin{array}{l}\text { 2019; Humbani and Wiese } \\
\text { 2018; Koenig-Liu et al. } \\
\text { 2019b; Park et al. 2019b }\end{array}$ & Johnson et al. 2018; Park et al. 2019b \\
\hline Uncertainty & 1 & $\begin{array}{l}\text { Xin et al. 2015; Gao and Waechter } \\
2017\end{array}$ \\
\hline
\end{tabular}

\section{Discussion}

In recent years, the use of mobile devices and mainly smartphones has sparked the adoption of mobile payments by buyers and sellers. As a new payment channel, m-payment has resulted in an increase in the volume of literature devoted to the subject (Zarmpou et al. 2012), most of which are from the perspective of consumers. According to the extant literature, various factors were selected to examine the adoption of m-payment services and systems; and different research theories and methodologies were applied. Classifying the accumulated literature between 2015 and 2019 regarding individual's adoption in m-payment systems, the following outcomes are the most common results by the researchers; according to the above umbrella review and scoping review. 


\subsection{Umbrella Review}

\subsubsection{Technology Adoption Theories and Intention Models}

Based on the research outputs of Karsen et al. (2019), the most commonly conducted framework theories and methodologies to explore m-payments acceptance regarding customers' behavioral intention were TAM $(22 \%)$, TAM extensions ( $26 \%$ ), as well as the combination of several theories, such as TAM, Theory of Reasoned Action / TRA, UTAUT and Theory of planned behavior (TPB).

TAM, along with its related extensions, was the first most popular and widely used methological framework in most research approaches of m-payment customers' adoption, due to its explanatory power and robustness. UTAUT, which is also subject to modification since its first appearance, has been gaining more attention from researchers in recent years. Most researchers focused on consumer behavior, with constructs and factors such as: ease of use, usefulness, trust, security, privacy, and behavior intention.

\subsubsection{Constructs/ Factors that Encourage or Inhibit M-Payment Adoption}

The analysis results of Liu et al. (2019a) revealed that all studies that were conducted in Asian countries focused primary on factors, such as perceived usefulness, perceived ease of use, perceived risk, trust and social influence. In Western countries, subject norm, attitude and perceived innovativeness are the most preferred ones. However, perceived innovativeness, perceived usefulness, attitude to use, perceived ease of use, attitude and subject norm were all discussed. Nevertheless, previous research attempts haven't explicitly studied factors taking into consideration the culture and regulation issues. Thus Liu et al. (2019a), in their meta-analysis study, although they did not use culture or regulations as independent factors on their own, they initiated them as sub-factors implicitly contained in the place factor. Recently studies (e.g., Dennehy \& Sammon 2015) examined technology, security and architecture regarding adoption issues. Although there is an increase in the specific studies per country, there are no research attempts that adopt a comparative study exploring data and results of multiple countries. Performance expectancy and perceived usefulness, followed by perceived ease of use revealed as the major factors influencing consumers' behavioral intention to use m-payments. Furthermore, as major inhibitor to the adoption of m-payments, "perceived risk" was found (Patil et al., 2017). In specific, the 10 most important factors for using m-payments are (Karsen et al., 2019): perceived ease of use, perceived security, perceived trust, perceived risk, perceived usefulness, social influence, effort and performance expectancy, attitude, and facilitating condition.

Thus, the most investigated constructs were perceived ease of use and perceived usefulness, following by perceived risk, trust, security, perceived enjoyment, personal innovativeness, self-efficacy, and perceived cost. Due to the astonishing increase in the use of m-payments, users are more concerned about their privacy and security when trading on their mobile devices. Due to the phenomenal rise in the usage of m-payments, users are more concerned about their privacy and security while performing transactions on their mobile devices.

Suggestions for future research is to incorporate social, cultural and regulatory influences as separate study factors, as consumers' behavioral intentions are influenced by culture or regulations environmental drivers as well.

\subsection{Scoping Review}

\subsubsection{Technology Adoption Theories and Intention Models}

Commonly to umbrella review, apart from TAM which was greatly applied from the researchers of the sample, the UTAUT was also utilized to a significant extent as well. In specific, in five studies the UTAUT was applied as the basic model and was further improved with other factors for a more holistic approach of the m-payment adoption examination by the researchers. Similar to TAM, UTAUT was also used as a part of a joint conceptual model. Apart from these two well-known behavioral decision models, there were other technology adoption theories that were applied from the academic community such as DOI, TPB, Technology Readiness Index (TRI) and UTAUT2. Finally, five studies examined m-payment adoption intention via a self-developed conceptual framework/ model deployed by their researchers (see Table 5).

\subsubsection{Constructs/ Factors that Encourage or Inhibit M-Payment Adoption}

Regarding enablers, trust was confirmed in almost half of the papers (11), followed by social influence (9), performance expectancy (7), security (6), compatibility (5), perceived ease of use (5), perceived usefulness (5) and facilitating conditions (4), whereas the rest of the enablers were applied 3 times or less in the empirical papers (see Table 6). Based on the results, it can be deduced that individuals paid a lot of attention to trust measures that m-payment systems and services applied. Therefore, the more trustful the transactional conditions 
are, the more acceptable m-payment is to be adopted by the smartphone users (e.g., Phonthanukitithaworn, 2016b; Qasim \& Abu-Shanab, 2016; Shankar \& Datta, 2018). Concerning the rest of the enablers that were used more frequently in the literature, the results came as no surprise. With the exception of security and compatibility, all of them are fundamental factors in both TAM and UTAUT, which are the basic technology adoption models utilized by the researchers. Concerning security, it is a vital factor in online transactions and is widely used in the e-commerce research field (e.g., Makki and Chang 2015; Guzzo et al. 2016; Lai 2018b). Therefore, the mobile industry should examine all the parameters that make an individual feel secured to adopt and further use $\mathrm{m}$-payment solutions. With reference to compatibility, the studies proved that $\mathrm{m}$-payment will have more chances to be adopted if it fits well with individuals' lifestyle and the way they like to conduct payment transactions. Therefore, mobile IT companies should adapt m-payment features to the contemporary way of living and the specific characteristics of individuals in order to lure even more of them to adopt m-payments.

Regarding the inhibitors, risk was the most deterrent factor on adopting m-payment by far (8), followed by cost (3) (see Table 6). Moreover, risk was also proved to impact indirectly m-payment adoption in various papers (4). The importance of risk may be attributed to the doubts associated with technological and monetary issues. The rest of the inhibitors -asset specificity, insecurity, opportunism of the mobile service provider/ vendor and technology anxiety- were confirmed in only one out of the 27 empirical studies, with the exception of uncertainty, which was proved to impact both directly (1) and indirectly (2) m-payment adoption. Therefore, the mobile industry should examine more meticulously the reasons why individuals feel risky to adopt m-payments and find ways to minimize their hesitations.

Finally, the scoping review analysis revealed that despite the fact that m-payment adoption is greatly investigated in Asia, there are comparatively few studies in the rest of the globe. Especially in the western world where the majority of the developed countries are belong to; the number of top academic papers that were published during the last five years is small. Thus, it can be deduced that there is a significant research gap that definitely needs much more attention from the academic community. The slow m-payment adoption rates along with the lack of empirical studies in the pre-adoption stage reveal a field that definitely needs to be further examined.

\section{Conclusion}

The main contribution of this research is twofold. First, it collects and summarizes m-payment adoption literature review papers published between 2015 and 2019 as an umbrella review. Second, it analyzes all recently top quantitative primary research papers, which investigated individuals' $m$-payment adoption intention the last five years as a scoping review. Both of these analyses help to provide a comprehensive and updated view of the topic; and can be used as a guide from researchers and practitioners who are involved in the study of m-payments' adoption. Thus, the paper helps to increase the understanding related to m-payment adoption as well as summarize the contemporary underlying factors that influence individuals' decision to accept $\mathrm{m}$-payments. The results present the technology adoption theories and intention models utilized by researchers, along with the factors that impact positively and negatively individuals to adopt m-payments. Furthermore, the study summarizes the most influential empirical studies on the topic along with the countries where researchers have spent too much effort on it. Overall, this paper helps to provide a complete understanding of m-payments adoption by individuals, the current trends and future challenges. As far as it is concerned, this is the first contemporary literature review paper that both includes an umbrella and a scoping review; and utilized such a strict criteria to reveal the top quality studies on the m-payment adoption field.

Concerning the managerial implications, the industry can greatly be benefited from the summarization of the main factors that impact positively of negatively individuals' m-payment adoption. Therefore, analogous actions can be taken place from the practitioners in order to minimize the constraints that inhibitors make to people. The fewer the perceived inhibitors the more adopted m-payments will be. On the other hand, the more enablers the proposed m-payment service has the more receptive can be. Therefore, managers can definitely use Table 6 as a guide to convince individuals adopt their m-payment services. Thus, the article provides an up-to-date both umbrella and scoping review of the topic and presents a holistic examination of individuals' m-payment adoption.

Due to the multiple factors and the different conditions depending on the technology of m-payment systems applied, but also the other drivers of the environment in which the customer operates, the mapping of consumer adoption behaviors contains pitfalls and difficulties, so that the outcoming results of a literature review cannot be easily generalized. Thus, obstacles and limitations arising from the analysis of previous literature reviews are that the time periods, sources (online academic publication databases), number of involved articles, and key terms used in several reviews of papers are different in each study. The next issue that needs special attention is 
the characterization of different countries' or market's environment. Researchers need to establish a list of specific features that differentiate countries and markets, as each mobile payment service market is known to be different but they do not know which factors best characterizes the variations in different countries.

A very important issue for the analysis of the findings is the evolution of m-payment systems and technologies as they evolve over time in the context of the e-commerce growth. The respective techniques seem to have different acceptance by consumers, depending both on the ease of use and safety they offer and the personal characteristics of the customers involved, such as innovativeness, familiarity and education. We recommend and encourage future researchers to focus on comparative research on the security and trust of each m-payment technology/ service, exploring the factors that influence customer adoption and preferences.

Furthermore, today, many consumers have the opportunity to experience m-payments, while a great number of payment alternatives and systems try to reach the intended end users. Aspects also contributing to the ever-increasing demand for m-payment services constitute both innovative easy to use m-payment systems/ services, familiarity of customers, merchant providers (bonus, motivation, infrastructure availability, merchant provisions, etc.) and the influence of environmental factors, such as social/ cultural, legal and further market factors (e.g., COVID-19 epidemic, lockdown, debt crisis and financial bans, legislation).

Therefore, general studies on m-payment customers' adoption contribute only to a partial understanding of mobile payments. We suggest for future research the specific m-payment systems in comparison with different countries and markets, in order to provide new insights taking into consideration the characteristics of the customers regarding the different mobile payment technologies and markets (multi-technologies, multi-country and multi-market studies).

As we still know so little about merchants', m-payment service providers' and other actors' (device manufacturers, regulators, financial institutions, etc.) impact, it is also interesting to explore their possible influential role towards individuals' adoption of m-payments.

\section{References}

Anderson, S., Allen, P., Peckham, S., \& Goodwin, N. (2008). Asking the right questions: Scoping studies in the commissioning of research on the organisation and Delivery of health services. Health Research Policy and Systems, 6(1), 7. https://doi.org/10.1186/1478-4505-6-7

Arksey, H., \& O`Malley, L. (2005). Scoping studies: towards a methodological framework. International Journal of Social Research Methodology, 8(1), 19-32. https://doi.org/10.1080/1364557032000119616

Becker, L. A., \& Oxman, A. D. (2008). Overviews of Reviews. Cochrane Handbook for Systematic Reviews of Interventions, 607-631.

Chandra, Y. U. (2017). Bank vs Telecommunication E-Wallet: System Analysis, Purchase, and Payment Method of GO Mobile CIMBNiaga and T-Cash Telkomsel. 2017 International Conference on Information Management and Technology (ICIMTech):165-170, Yogyakarta, Indonesia.

Chen, W. C., Chen, C. W., \& Chen, W. K. (2019). Drivers of Mobile Payment Acceptance in China. Information, 10, 384. https://doi.org/10.3390/info10120384

Dahlberg, T., Guo, J., \& Ondrus, J. (2015). A critical review of mobile payment research. Electronic Commerce Research and Applications, 14, 265-284. https://doi.org/10.1016/j.elerap.2015.07.006

Dahlberg, T., Mallat, N., Ondrus, J., Zmijewska, A. (2008). Past, present and future of mobile payments research: A literature review. Electronic Commerce Research and Applications, 7, 165-181. https://doi.org/10.1016/j.elerap.2007.02.001

Daudt, H. M., Van Mossel, C., \& Scott, S. J. (2013). Enhancing the scoping study methodology: A large, inter-professional team's experience with Arksey and O'Malley's framework. BMC Medical Research Methodology, 13(1), 48. https://doi.org/10.1186/1471-2288-13-48

Dennehy, D., \& Sammon, D. (2015). Trends in mobile payments research: A literature review. Journal of Innovation Management, 3(1), 49-61. https://doi.org/10.24840/2183-0606_003.001_0006

Gao, L., \& Waechter, A. K. (2017). Examining the role of initial trust in user adoption of mobile payment services: An empirical investigation. Information Systems Frontier, 19, 525-548. https://doi.org/10.1007/s10796-015-9611-0

Guzzo, T., Ferri, F., \& Grifoni, P. (2016). A model of e-commerce adoption (MOCA): Consumers' perceptions and behaviours. Behaviour and Information Technology, 35(3), 196-209. 
https://doi.org/10.1080/0144929X.2015.1132770

Harris, M., Chin, A., \& Beasley, J. (2019). Mobile payment adoption: An empirical review and opportunities for future research. SAIS 2019 Proceedings, 8. https://doi.org/10.3390/info10120384

Humbani, M., \& Wiese, M. (2018). A Cashless Society for All Determining Consumers Readiness to Adopt Mobile Payment Services. Journal of African Business, 19(3), 409-429. https://doi.org/10.1080/15228916.2017.1396792

Johnson et al. (2018). Limitations to the rapid adoption of M-payment services: Understanding the impact of privacy risk on M-Payment services. Computers in Human Behavior. 30(2), 186-197. https://doi.org/10.1016/j.chb.2017.10.035

Karsen, M., Chandra, U. Y., \& Juwitasary, H. (2019). Technological factors of mobile payment: A systematic literature review. Procedia Computer Science, 157, 489-498. https://doi.org/10.1016/j.procs.2019.09.004

Kitchenham, B. A., Budgen, D., \& Pearl Brereton, O. 2011. Using mapping studies as the Basis for further research - a participant-observer case study. Information and Software Technology, 53(6), 638-651. https://doi.org/10.1016/j.infsof.2010.12.011

Koenig-Lewis, N., Marquet, M., Palmer, A., \& Zhao L. A. (2015). Enjoyment and social influence predicting mobile payment adoption. The Service Industries Journal, 35(10), 537-554. https://doi.org/10.1080/02642069.2015.1043278

Lai, P. C. (2017b). Security as an extension to TAM model: Consumers' intention to use a single platform e-payment. Asia-Pacific Journal of Management Research and Innovation, 13(3/4), 110-119. https://doi.org/10.1177\%2F2319510X18776405

Lai. P. C. (2017a). The literature review of technology adoption models and theories for the novelty technology. Journal of Information Systems and Technology Management, 14(1), 21-38.

Lee, J., Ryu, H. M., \& Lee, D. (2019). A study on the reciprocal relationship between user perception and retailer perception on platform-based mobile payment service. Journal of Retailing and Consumer Services, 48, 7-15. https://doi.org/10.1016/j.jretconser.2019.01.007

Levac, D., Colquhoun, H., \& O'Brien, K. K. (2010). Scoping studies: advancing the methodology. Implementation Science, 5(1), 69. http://dx.doi.org/10.1186/1748-5908-5-69

Liébana-Cabanillas, F., Sánchez-Fernández, J., \& Muñoz-Leiva, F. (2014). Antecedents of the adoption of the new mobile payment systems: The moderating effect of age. Computers in Human Bevavior, 35, 464-478. https://doi.org/10.1016/j.chb.2014.03.022

Liébana-Cabanillas, M. V., Ramos de Luna, I., \& Kalinic, Z. (2018). Predicting the determinants of mobile payment acceptance A hybrid SEM-neural network approach. Technological Forecasting and Social Change, 129, 117-130. https://doi.org/10.1016/j.techfore.2017.12.015

Liu, Y., Wang, M., Huang, D., Huang, Q., Yang, H., and Li, Z. 2019b. The impact of mobility, risk, and cost on the users' intention to adopt mobile payments. Information Systems and e-Business Management, 17, 319-342. https://doi.org/10.1007/s10257-019-00449-0

Liu, Z., Ben, S., \& Zhang R. (2019a). Factors affecting consumers' mobile payment behavior: A meta-analysis. Electronic Commerce Research, 19, 575-601. https://doi.org/10.1007/s10660-019-09349-4

Makki, E., \& Chang, L. (2015). E-commerce Acceptance and Implementation in Saudi Arabia, Previous, Current and Future Factors. The International Journal of Management Research and Business Strategy, 4(3), 29-44.

Mallat, N. (2007). Exploring consumer adoption of mobile payments: A qualitative study. The Journal of Strategic Information Systems, 16(4), 413-432. https://doi.org/10.1016/j.jsis.2007.08.001

Merchantsavvy. (2020). Amazing stats demonstrating the unstoppable rise of mobile payments globally. Retrieved from https:/www.merchantsavvy.co.uk/mobile-payment-stats-trends/

Moorthy, K., T’ing C. L., Yee, C. K., Huey, W. A., In, J. L., Feng, C. P., \& Yi, J. T. (2019). What drives the adoption of mobile payment, A Malaysian perspective. International Journal of Finance and Economics, 25(3), 349-364. https://doi.org/10.1002/ijfe.1756

Musa, A., Khan, U. H., \& AlShare, A. K. (2015). Factors influence consumers' adoption of mobile payment devices in Qatar. International Journal of Mobile Communications, 13(6), 670-689. https://doi.org/10.1504/IJMC.2015.072100 
Oliveira, T., Thomas, M., Baptista, G., \& Campos, F. (2016). Mobile payment Understanding the determinants of customer adoption and intention to recommend the technology. Computers in Human Behavior, 61, 404-414. https://doi.org/10.1016/j.chb.2016.03.030

Pal. A., De, R., Herath, T., \& Raghav Rao, H. (2019). A review of contextual factors affecting mobile payment adoption and use. Journal of Banking and Financial Technology, 3, 43-57. https://doi.org/10.1007/s42786-018-00005-3

Paré, G., Trudel, M. C., Jaana, M., \& Kitsiou, S. (2015). Synthesizing information systems knowledge: A typology literature reviews. Information \& $\quad$ Management, $\quad 52, \quad 183-199$. https://doi.org/10.1016/j.im.2014.08.008

Park, J., Ahn, J., Thavisay, T., \& Ren, T. (2019). Examining the role of anxiety and social influence in multi-benefits of mobile payment service. Journal of Retailing and Consumer Services, 47, 140-149. https://doi.org/10.1016/j.jretconser.2018.11.015

Park, J., Amendah, E., Lee, Y., \& yun, H. (2019). M-payment service: Interplay of perceived risk, benefit, and trust in service adoption. Human Factors and Ergonomics in Manufacturing and Services Industries, 29, 31-43. https://doi.org/10.1002/hfm.20750

Patil, P. P., Dwivedi, K. Y., \& Rana, P. N. (2017). Digital payments adoption: An analysis of literature. In Kar A. et al. (Eds.), Digital Nations - Smart Cities, Innovation, and Sustainability. Lecture Notes in Computer Science, (p. 10595). Springer, Cham. https://doi.org/10.1007/978-3-319-68557-1

Phonthanukitithaworn, C., Sellitto, C., \& Fong, W. L. M. (2016a). A Comparative Study of Current and Potential Users of Mobile Payment Services. Sage Open, 1-14. https://doi.org/10.1177/2158244016675397

Phonthanukitithaworn, C., Sellitto, C., \& Fong, W. L. M. (2016b). An investigation of mobile payment (m-payment) services in Thailand. Asia-Pacific Journal of Business Administration, 8(1), 37-54. https://doi.org/10.1108/APJBA-10-2014-0119

Qasim, M. H., \& Abu-Shanab, E. (2016). Drivers of mobile payment acceptance: The impact of network externalities. Information Systems Frontier, 18(5), 1021-1034. https://doi.org/10.1007/s10796-015-9598-6

Rumrill, P. D., Fitzgerald, S. M., \& Merchant, W. R. (2010). Using scoping literature reviews as a means of understanding and interpreting existing literature. Work: A Journal of Prevention, Assessment and Rehabilitation, 35(3), 399-404. https://doi.org/10.3233/WOR-2010-0998

Shahin, A., \& Mahyari, K. H. (2019). Identifying and evaluating cognitive factors influencing the acceptance of mobile payment services. International Journal of Services and Operations Management, 34(2), $210-227$. https://doi.org/10.1504/IJSOM.2019.103060

Shankar, A., \& Datta, B. (2018). Factors Affecting Mobile Payment Adoption Intention: An Indian Perspective. Global Business Review, 19(35), 725-895. https://doi.org/10.1177/0972150918757870

Sharma, K. S., Sharma, H., \& Dwivedi, K. Y. (2019). A Hybrid SEM Neural Network Model for Predicting Determinants of Mobile Payment Services. Information Systems Management, 36(3), 243-261. https://doi.org/10.1080/10580530.2019.1620504

Sinha, M., Majra, H., Hutchins, J., \& Saxena, R. (2019). Mobile payments in India the privacy factor. International Journal of Bank Marketing, 37(1), 192-209. https://doi.org/10.1108/IJBM-05-2017-0099

Slade, L. E., Dwivedi, K. Y., Piercy, C. N., and Williams, D. M. 2015. Modeling Consumers' Adoption Intentions of Remote Mobile Payments in the United Kingdom Extending UTAUT with Innovativeness, Risk, and Trust. Psychology and Marketing 32 (8), 860-873.

Smith, V., Devane, D., Begley, C. M., and Clarke, M. 2011. Methodology in conducting a systematic review of systematic reviews of healthcare interventions. BMC Medical Research Methododology 11 (1), 15. https://doi.org/10.1186/1471-2288-11-15

Su, P., Wang, L., and Yan, J. 2018. How users Internet experience affects the adoption of mobile payment a mediation model. Technology Analysis and Strategic Management 30 (2), 186-197. https://doi.org/10.1080/09537325.2017.1297788

Tansakul, P., Halgamuge, M., Syed. A. 2019. Distinguish significant adoption factors that influence users' behavioral expectation to utilize mobile payment: A survey. In Akgül Y. (Eds.), Structural Equation Modeling Approaches to E-Service Adoption (pp. 148-168). Igi-Global, Pennsylvania, USA. https://doi.org/10.4018/978-1-5225-8015-7.ch009 
Teo, A. C., Tan, G. W. H., Hew, T. S., \& Yew, K. T. (2015a). The effects of convenience and speed in m-payment. Industrial Management and Data Systems, 115(2), 311-331. http, //dx.doi.org/10.1108/IMDS-08-2014-0231

Teo, A. C., Tan, G. W. H., Ooi, K. B., \& Lin, B. (2015b). Why consumers adopt mobile payment A partial least squares structural equation modelling (PLS-SEM) approach. International Journal of Mobile Communications, 13(5), 478-497. https://doi.org/10.1504/IJMC.2015.070961

Ting, H., Yacob, Y., Liew, L., \& Lau, M. W. (2016). Intention to Use Mobile Payment System: A Case of Developing Market by Ethnicity. Procedia Social and Behavioral Sciences, 224(15), 368-375. https://doi.org/10.1016/j.sbspro.2016.05.390

Tricco, C. A., Lilie, E., Zarin, W., O’Brien, K., \& Colquhoun, H., et al. (2016). A scoping review on the conduct and reporting of scoping reviews. BMC Medical Research Methodology, 16, 15. https://doi.org/10.1186/s12874-016-0116-4

Tse, D., Wen, T., Wu, R., Yin, G., \& Zhai, X. (2019). Factors affecting customer acceptance of mobile payment. Proceedings of the 2019 IEEE IEEM (pp. 1089-1093). Macau, China.

Xin, H., Techatassanasoontorn, A. A., \& Tan B. F. (2015). Antecedents of Consumer Trust in Mobile Payment Adoption. Journal of Computer Information Systems, 55(4), 1-10. https://doi.org/10.1080/08874417.2015.11645781

Yan, H., \& Yang, Z. (2015). Examining mobile payment user adoption from the perspective of trust transfer. International Journal of $u$ - and $e^{-}$Service, Science and Technology, 8(1), 117-130. https://doi.org/10.1504/IJNVO.2015.070423

Zarmpou, T., Saprikis, V., Markos, A., \& Vlachopoulou, M. (2012). Modeling users' acceptance of mobile service. Electronic Commerce Research, 12, 225-248. https://doi.org/10.1007/s10660-012-9092-x

\section{Copyrights}

Copyright for this article is retained by the author(s), with first publication rights granted to the journal.

This is an open-access article distributed under the terms and conditions of the Creative Commons Attribution license (http, //creativecommons.org/licenses/by/4.0/). 